九州大学学術情報リポジトリ

Kyushu University Institutional Repository

\title{
Effect of Virogenic Hydroxylamine-Metabolites on Deoxyribonucleic Acid and RNA-Polymerase
}

Omura, Hirohisa

Food Chemistry Institute, Department of Food Science and Technology, Faculty of Agriculture, Kyushu University

I iyama, Satoru

Food Chemistry Institute, Department of Food Science and Technology, Faculty of Agriculture, Kyushu University

Fuji i, Takato

Food Chemistry Institute, Department of Food Science and Technology, Faculty of Agriculture, Kyushu University

Yamafuji, Kazuo

Food Chemistry Institute, Department of Food Science and Technology, Faculty of Agriculture, Kyushu University

https://doi.org/10.5109/22829

出版情報：九州大学大学院農学研究院紀要. 17 (2)，pp.181-186，1973-03. Kyushu University バージョン：

権利関係: 


\title{
Effect of Virogenic Hydroxylamine-Metabolites on Deoxyribonucleic Acid and RNA-Polymerase
}

\author{
Hirohisa Omura, Satoru Iiyama, Takato Fujii \\ and \\ Kazuo Yamafuji \\ Food Chemistry Institute, Department of Food Science and Technology, \\ Faculty of Agriculture, Kyushu University, Fukuoka
}

(Received September 5, 1972)

\begin{abstract}
Single strand scission in duplex DNA is caused by hydroxylamine, Na-nitrite or oximes of glucose and galactose of proper low molarities. The suitable nicking in the DNA-molecule brings about the elevation of its template nature. Excessive breakage of DNA, however, reduces its template activity. The results have been discussed in relation to an effect causing cyto-differentiation and -anomalization.
\end{abstract}

\section{INTRODUCTION}

Hydroxylamine is the first reagent which was successfully used for virus induction (Yamafuji et al., 1944a; 1944b). Enzymatic studies on this amine have led us to the establishment of a cycle producing metabolic mutagens and virogens (Yamafuji, 1963 ; 1964 ; Yamafuji and Watanabe, 1964). The cycle includes nitrite and oxime. The present paper describes the effect of these three nitrogenous substances on the breakage of DNA-thread and the synthesis of mRNA.

\section{MATERIALS AND METHODS}

\section{Cleavage of DNA-strand}

DNA was prepared from calf thymus according to the method stated before (Yamafuji et al., 1966 ; 1971b). To prove the single strand scission (nick) in the double helix-molecule, a mixture of $40 \mu \mathrm{g} / \mathrm{ml}$ DNA in SSC (0.15 M NaCl $+0.015 \mathrm{M}$ Na-citrate, $\mathrm{pH}=7$ ) and hydroxylamine-metabolites of appropriate molarity was first incubated at 37" for $\mathbf{4} \mathrm{hrs}$., and a sucrose gradient centrifugation was then applied to the solution of $\mathrm{pH}=12.8$ for $4 \mathrm{hrs}$. at 30,000 r.p.m. In the control, DNA was incubated without metabolites and centrifuged in the same way.

\section{Alteration of RNA-polymerase}

The preparation of enzyme from $\boldsymbol{E}$. coli was carried out with the method of Ishihama and Kameyama (1967). In order to measure the enzymatic activity, 0.25 $\mu \mathrm{Ci}{ }^{14} \mathrm{C}$-4-UTP was mixed with $0.08 \mu$ moles ATP, $0.08 \mu$ moles GTP, $0.08 \mu$ moles CTP, $1.0 \mu$ moles $\mathrm{MgSO}_{4}, 0.4$ moles $\mathrm{MnSO}_{4}, 1.0$ pmoles mercaptoethanol, $2.4 \mu$ moles 
Tris-HCl buffer ( $\mathrm{pH}=7.8$ ), $20 \mu \mathrm{g}$ DNA and $150 \mu \mathrm{g}$ polymerase ; the total volume was $200 \mu \mathrm{l}$. At regular intervals at $37^{\circ}$, a portion of the mixture was mixed with 10 \%6 trichloroacetic acid. The precipitate was dissolved in $2 \mathrm{M} \mathrm{NH}_{4} \mathrm{OH}$ and counted in Beckman LS 250-fluid scintillation counter. The polymerase action was thus expressed in cpm. To determine the template activity, the nicked DNA prepared by 30 min.-pretreatment with metabolic virogens was used in the test after dialyzing against water for $16 \mathrm{hrs}$. at 5". In the control, the DNA incubated in the SSC-solution without virogens was employed after the dialysis in the same manner.

\section{RESULTS}

\section{Cleavage of DNA-strand}

In the preceding investigation (Yamafuji et al., 1971b), it was demonstrated that hydroxylamine or $\mathrm{KNO}$, in co-operation with $\mathrm{CuSO}_{4}$ breaks duplex DNA. We now investigated the effect in $\mathrm{NH}_{2} \mathrm{OH}$ or $\mathrm{NaNO}_{2}$ of much lower concentration on the DNA-breakage. As shown in Fig. 1, nicks produced in a $5 \times 10^{-5} \mathrm{M}$ amine or $5 \times 10^{-5} \mathrm{M}$ nitrite solution without copper.

It was also observed previously (Murakami and Yamafuji, 1970) that glucosor galactosoxime $+\mathrm{Cu}$ cleaves native DNA. As illustrated in Fig. 2, we found here that single strand cleavages can be caused by $5 \times 10^{-6} \mathrm{M}$ oximes in the absence of $\mathrm{Cu}$-salt.

The nick formation was further examined using DNA which had been pre-

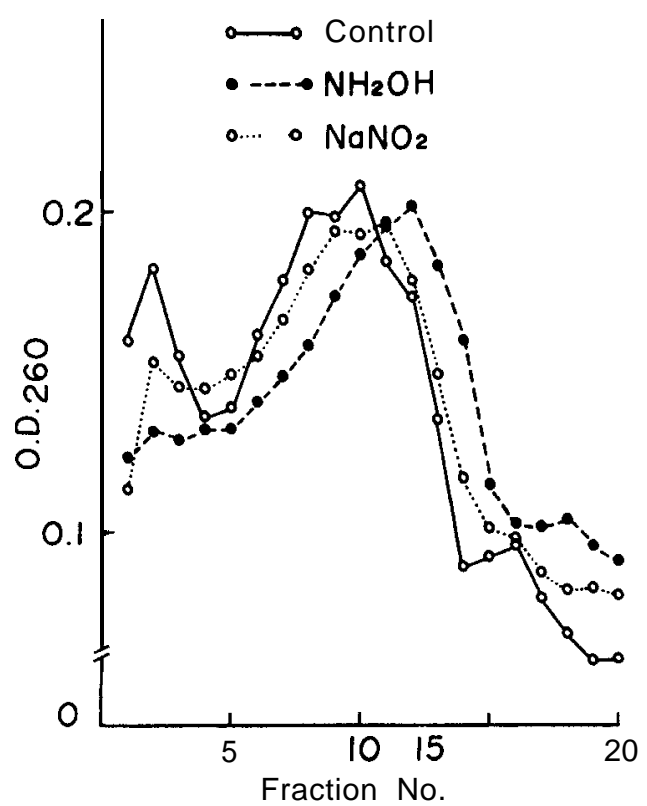

Fig. 1. Sedimentation pattern of $\mathrm{DNA}$ at $\mathrm{pH}=12.8$ after treating with $\mathrm{NH}_{2} \mathrm{OH}$ or $\mathrm{NaNO}_{2}$. 


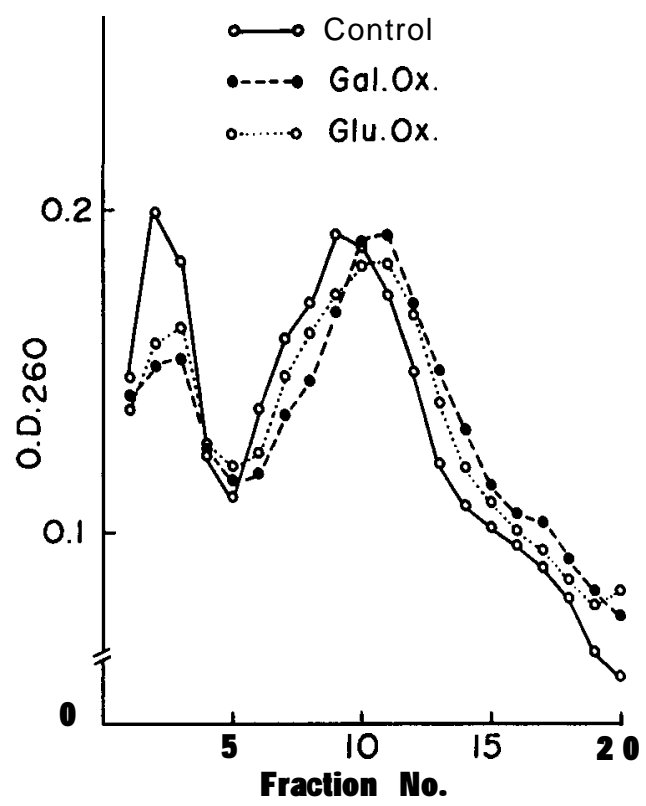

Fig. 2. Sedimentation pattern of DNA at $\mathrm{pH}=12.8$ after treating with glucos- or galactosoxime.

treated with hydroxylamine-metabolites for $30 \mathrm{~min}$. The patterns obtained were the same as those in the above figures, but their peaks were pretty low.

\section{Alteration of RNA-polymerase}

In the previous paper (Yamafuji et al., 1972), it was reported that the activity of RNA-polymerase is affected by the combined action of noradrenaline and $\mathrm{CuSO}_{4}$. We now estimated the template potentiality of DNA pretreated with virogenic metabolites of relatively low and rather high molality without cooperation of $\mathrm{Cu}$. The experiment disclosed that, as is evident from Fig. 3, an activation of enzyme occurs in the solution containing DNA treated with $5 \times 10^{-5}$ $\mathrm{M}$ hydroxylamine. When the DNA was pretreated with $5 \times 10^{-2} \mathrm{M}$ amine, however, the polymerase was inactivated remarkably. This may be due to double strand-breaks of considerable amount. Taylor et al. (1970) proved that treatment of T7 DNA with $0.5 \mathrm{M} \mathrm{NH}_{2} \mathrm{OH}$ inhibits transcription of this template by coliRNA polymerase.

In the tests of DNA-splitting by hydroxylamine and $\mathrm{NaNO}_{2}$, it was found that the nick-producing ability of the former is higher than that of the latter. As is obvious from Fig. 4, the template potency of DNA pretreated with diluted nitrite solution was lower than that of the one treated with the amine of the same concentration. The observation suggests that the RNA-polymerase activity is proportional to the nicking grade in DNA-molecules. It was further observed 


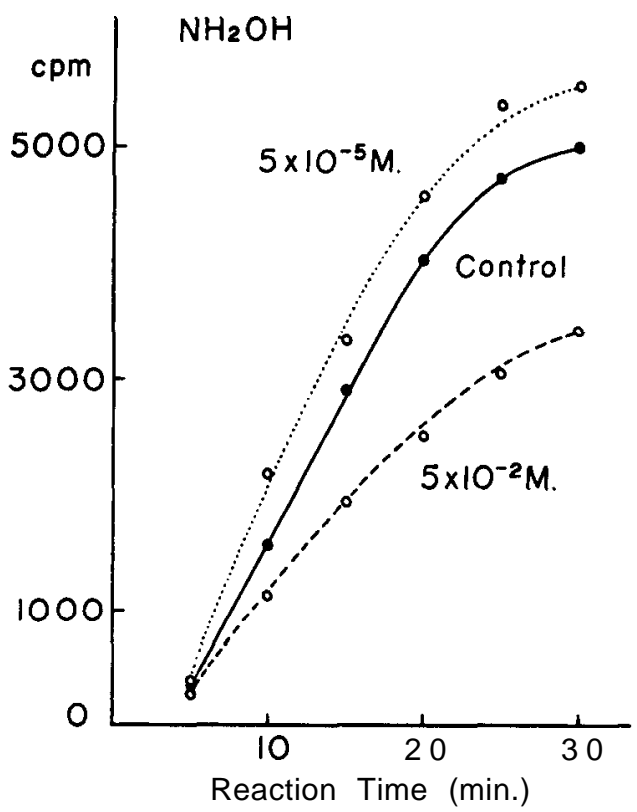

Fig. 3. RNA-polymerase activity in solution containing DNA pretreated with $\mathrm{NH}_{2} \mathrm{OH}$.

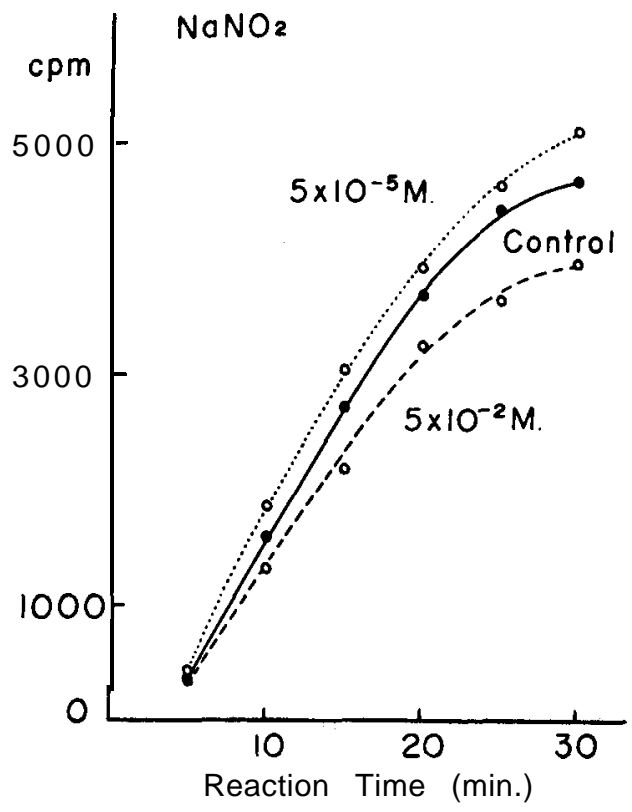

Fig. 4. RNA-polymerase activity in solutions containing DNA pretreated with $\mathrm{NaNO}_{2}$. 


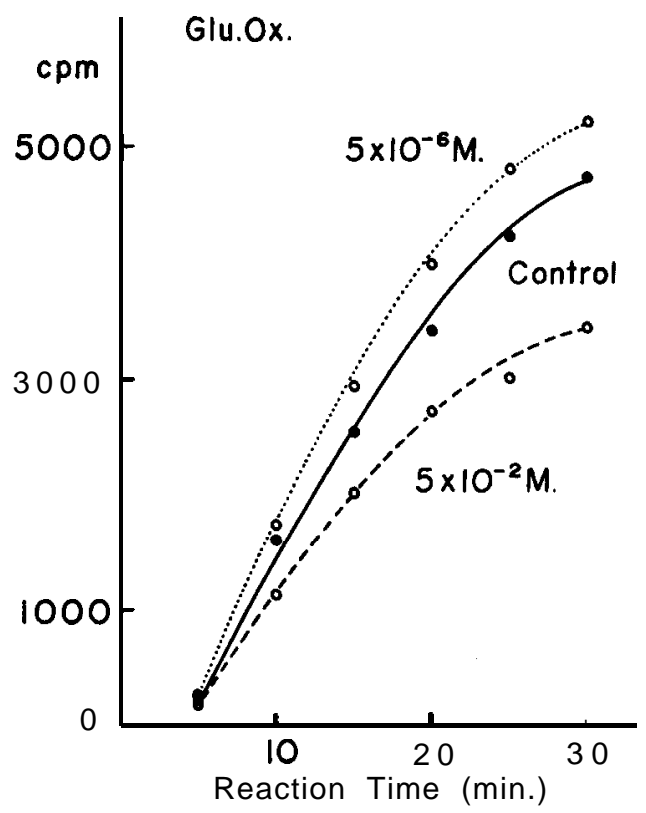

Fig. 5. RNA-polymerase activity in solutions containing DNA pretreated with glucosoxime.

that NO, of high normality also hinders the transcriptional capacity of DNA.

Glucosoxime has been regarded as one of the best polyhedral virus inducers and its toxic action is weak. As depicted in Fig. 5, the template capability of DNA was elevated by treating it with $5 \times 10^{-6} \mathrm{M}$ glucosoxime. The treatment of DNA with $5 \times 10^{-2} \mathrm{M}$ oxime, however, weakened its activity.

\section{DISCUSSION}

Cytoanomalizations including virogenesis would be primarily introduced by deviation of DNA-duplication and mRNA-synthesis. For instance, production of viral polyhedrosis necessiates intensive replication of special fragment of chromosomal DNA and rapid formation of specific protein by newly synthesized RNA. The activation of template nature of DNA by metabolic virogens should mean the synthesis of new RNA by polymerase. The formation of abnormal protein, therefore, can be the result of appropriate nicking in DNA-molecules. The present investigation may thus give a support for the formulation (Yamafuji et al., 1971a) of an effect causing cellular differentiation and anomallzation.

\section{REFERENCES}

Ishihama, A. and T. Kameyama 1967 The molecular mechanism of enzymic reaction in RNA synthesis. Biochim. Biophys. Acta, 138, 480

Murakami, H. and K. Yamafuji 1970 Mode of action of some catecholamines and sugar oximes on deoxyribonucleic acid. Enzymol., 38, 337 
Taylor, A. T., S. B. Crist and 0. W. Jones 1970 Alteration of native DNA transcription by the mutagen hydroxylamine. Cancer Research, 30, 95

Yamafuji, K. 1963 A metabolic cycle producing virogens and mutagens. Agric. Biochem. Kyushu Univ., 23, 13

Yamafuji, K. 1964 Metabolic virogens having mutagenic action and chromosomal previruses. Enzymol., 27, 217

Yamafuji, K., F. Hashinaga and T. Fujii 1966 Isolation and identification of polyhedral pre-viral deoxyribonucleic acid from healthy silkworm cells. Enzymol., 31, 92

Yamafuji, K., S. Iiyama and H. Murakami 1972 Action of noradrenalin on brain nucleic acids and RNA-polymerase. Enzymol., 42, 439.

Yamafuji, K., S. Iiyama and K. Shinohara 1971a Mode of action of steroid hormones on deoxyribonucleic acid. Enzymol., 40, 259

Yamafuji, K., K. Shinohara, F. Yoshihara, M. Iio and Y. Torikai 1971b Breakage of nucleic acids as initiative process of cytodifferentiation and cytoanomalization. Enzymol., 40,107

Yamafuji, K. and Y. Shirozu 1944a Die Abhängigkeit der Neubildung des Virusproteins von Erniedrigung der Katalase. Biochem. Zs., 317, 94

Yamafuji, K., S. Takeoka and T. Fujiki 1944b On the production of virus in living organisms. J. Agric. Chem. Soc. Japan., 19, 225

Yamafuji, K. and K. Watanabe 1964 Mutagenic action of hyponitrous acid and glucose oxime. Nature, 203, 409 